\title{
EDUCATIONAL DEVELOPMENT PRIORITIES FOR PEOPLE WITH SPECIAL NEEDS IN UKRAINE
}

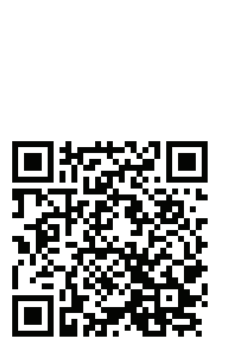

To cite this article:
Vyacheslav Zasenko, Dr. Sc., Prof.

Director,

Mykola Yarmachenko Institute

of Special Pedagogy and Psychology,

National Academy of Educational Sciences of Ukraine,

Kyiv, Ukraine

isenaesu@gmail.com

https://orcid.org/0000-0003-0325-4578

\section{Lesya Prokhorenko, Dr. Sc., Senior Researcher}

Head, Department of Support for Children with Special Needs, Mykola Yarmachenko Institute of Special Pedagogy and Psychology,

National Academy of Educational Sciences of Ukraine,

Kyiv, Ukraine

lesya-prohor@ukr.net

https://orcid.org/0000-0001-5037-0550

Zasenko, V. \& Prokhorenko, L. (2018). Educational development priorities for people with special needs in Ukraine. Education: Modern Discourses, 1, 161-166. https://doi.org/10.32405/2617-3107-2018-1-15

\begin{abstract}
The article is an attempt to outline general aspects of educational system reforming for the people with special needs in Ukraine, to disclose concisely the key ways of modernization, and to characterize positive shifts in educational area. The article states that integrative principle of national educational system establishment is in its quality. It describes global changes in special education area occurred during the last years. It is acknowledged that Ukraine is reorganizing educational system in order to bring it into accord with market economy requirements and open democratic society under the theme of enabling equitable access to quality education for all children with special educational needs. The point of education is seen as a main educational system transformation instrument, including special education, on competence principles. It is elucidated that separation from established practice of point structurization based on the substantive principle takes place, and it foresees the adequacy of educational content structure to scientific knowledge branches structure. Within competence attitude, concretization of school subjects' quantity is not a point of special education. Instead, identifying outcomes expected to be recovered on the national level are the point. Its comprehensiveness is reverberated in national standards being implemented in Ukraine.
\end{abstract}

Key words: educational area reforming; innovative learning technologies; children with special educational needs.

\section{INTRODUCTION. PROBLEM STATEMENT}

Under globalization, the international community positions educational quality as a prerequisite for economic success, social coherence and country's competitiveness. On the way toward transition to information society, it would be particularly valuable to re- 
alize that education should become a competitive kind of activity in which effectiveness and measurable results are major principles. One of such government policy principles is tolerant attitude to children with special educational needs as to productive members of society, who have equal rights and opportunities for studying, work, and social activity that generates rapid modernization processes in special education.

The legal framework (Laws of Ukraine "On Education", "Rehabilitation of People with Disabilities in Ukraine", etc.), and normative base (Decrees of the Cabinet of Ministers of Ukraine "Provisions for "Inclusive Resource Centre", "Organizational Arrangements for Inclusive Studying in General Education Institutions", "Terms and Conditions of Subvention Provision from the National Budget to the Local Budgets and Governmental Support for People with Special Educational Needs", etc.) testify to the effective governmental support of children with special needs.

The international experience of the leading European Union countries and theoretical and practical developments in building the education system with due regard for national heritage have become a source for creating a new model of special education in Ukraine. Special education reform is aimed at meeting educational demands of students with special needs. However, it is a difficult task. On the one hand, special education is to provide education accessibility, alternatives in forms and educational institutions, obtain desirable educational level in future as well as to enable necessary correctional, rehabilitation, psychological, and pedagogical coaching. On the other hand is to provide effective innovative technologies that comply with the best European standards.

\section{LITERATURE REVIEW}

Previous research demonstrates that the educational reforming "from up to down", popular in the $20^{\text {th }}$ century, leaves a little space for teacher and school self-consistency. Usually, such reforms result in a shift of main attention to separate factors that noticeably restrains educational and pedagogic process efficiency. Simultaneously, certain publications introduce concrete, based on special surveys, approaches to improve education (Ch. Webber, O. Hulai, D. Lupart, N. Remezovska, and others).

Modern researchers are still strongly disputing around the validation of different educational structure models, starting with phenomenological (A. Maslow, A. Combs, C. Rodgers etc.) and finishing with developmental theories (V. Davydov, V. Fliakov etc.) and inclusive learning model (V. Zasenko, A. Kolupaieva, O. Taranchenko, E. Danilavichute, O. Fedorenko, and others). The phenomenological model means person-oriented education, including considering children's individual and psychological special features. The developmental model means educational organization as a special infrastructure with a broad collaboration of different systems, types, and levels activities. The inclusive learning model is based on equal access to quality education for children with special educational needs; it stipulates their education organization at general educational institutions grounded on implementation of person-oriented educational methods and considering individual special features of development and scientific and educational activities of the children. In the context of the aforementioned problems, issues of special education efficiency, satisfaction of needs, interests, and abilities development of students with special educational needs are the focus of attention. In any case, the topical problem within paradigm of knowledge remains a breakaway between students' knowledge and abilities to implement it in different forms of life activities. 
Thus, satisfaction of various educational requests and needs of children with special needs plays a crucial role for the development and strengthening of innovatory tendencies in special education.

\section{METHODOLOGY}

Special education system modernization relies on a series of theoretical and methodological principles that allow organizing a strategy for defined tasks with orientation at the New Ukrainian School and focusing on inclusive educational form for children with special needs.

The National Doctrine of Education Development stipulates that equal access to quality children's education is a national priority and a precondition for implementation of international and national regulations regarding citizens' use of rights to obtain quality education. These principles are directly related to special pedagogy and psychology areas.

Consequently, general and obligatory principles for educational development for persons with special needs seem to be following:

- special education priority, which means shaping a new society's attitude to children with special needs;

- educational variability, which allows persons to use their rights for choosing educational forms, means, and educational, pedagogical, and professional measures types;

- democratization of education: giving all types of educational institutions self-consistency and creating a system of students, educators, parents, and community partnership in all areas of educational and pedagogical process;

- interventional orientation of education, which supports children's development based on use of their compensative possibilities.

To summarize, child-centrism, competency-based approach, and person-oriented education should become a leit-motif for the prioritized branch development.

\section{MAIN RESULTS}

In Ukraine, strategic approach for special education humanistic paradigm development is based on the universal human and European democracy values. The declared person-oriented, competency-oriented approach to education content design is connected with the recognition of knowledge importance as common wealth and progress engine. The changes are interrelated with creating new educational standards, updating and reviewing educational programs, content of educational-pedagogic materials, textbooks, and educational forms and methods.

Standardization of approaches to school educational process and its quality performances are shaping a tendency in school education reforms in Ukraine. Determined by Primary, Basic, and Complete General Education State Standards, educational goals are based on the principles of competency and activities approaches, implemented in educational areas and presented within resulting elements of education content. The commitment to New Ukrainian School's (NUS) formula foresees competency-oriented approach implementation. In accordance with NUS's conception, each discipline program contains a list of competences to be obtained as a result of current educational stage, a range of methodological advice is developed for teachers regarding students' assessment and teaching, in order to help students with special educational needs to master relevant competences. 
First, attention is focused on the improvement of interventional pedagogic process, modern theory and learning and teaching practice review, its content and forms upgrading, relevant learning and teaching supply, special school textbooks for all disciplines in particular. Indicated goals clearly outline learning outcomes as life competences achievement by students with special needs, enabling child to learn, accomplish social tasks, and react on requests of time.

The newly developed curricula are aimed to develop skills, abilities, and competences to act and apply knowledge in various situations. The state determines the goals and standard requirements, guidelines, control and assessment system; it also proposes norms and conditions that guarantee educational imperatives implementation. New learning plans are developed; they are learning outcomes-oriented: in order to organize academic process in accordance with students' educational needs, the assessment is required both at the beginning and in the end of each educational cycle.

Special education establishment is crucially dependent on inclusive and integrative processes, including different forms of common education and pedagogy of children with special needs and their healthy peers. However, the problem not only requires to integrate a child with special needs into the classes of general education school, but it also refers to the content, methods, and forms for teaching such category of children. Psychological surveys reveal that children with special educational needs face not only a problem to obtain knowledge and competences, but they also struggle with a problem of social isolation. The crucial point is to support these children by means of psychology and pedagogy via creation psychological service, practical psychologists' integration into education process. Having this in mind, the adaptation of children with special needs within educational environment becomes a primary importance task. Inadequate behaviour performances of children with special needs such as aggressiveness, strife, and secretiveness are strongly affiliated with integrative problems of becoming a group member. Due to this precise reason, social and psychological adaptation of these children in a group, their learning motivation strengthening should combine pedagogic impacts and special methods, technologies, and workshops implementation. Thereafter, nowadays educational and informational technologies of NUS along with corrective and developmental work oriented at a personal development of a child with special needs would enhance those children's educational effectiveness and quality, assisting their socialization.

It should be mentioned that Ukraine has made a pivotal progress in spreading inclusive learning. It comprises both spreading academic/theoretical principles development and learning/teaching supply. In particular, the Inclusive Learning Conception, relevant principles on inclusive learning organization (aforementioned), tutoring for educational institutions' qualification growth are developed. It started preparation and staff qualification growth for inclusive education institutions (the last is professionally provided by Ukraine Mykola Yarmachenko Institute of Special Pedagogy and Psychology of the National Academy of Educational Sciences of Ukraine).

Inclusive-Resource Centers (IRC) establishment is one of the most important areas in the development and modernization of Ukraine's special education system. Their a goal is to support children with special educational needs via psychological and pedagogical, interventional and developmental services, and supply qualified coach for these children, support the schools, families, and communities of these children integration. IRC's psychological and pedagogic assistance involves a complete assessment of the child's condition. The assessment includes the following: child's physical development assessment; child oral development assessment; child cognitive sphere assessment; child 
emotional-volitional sphere assessment; child learning activities assessment. If IRC professionals confirm the fact that a child has special needs, complete assessment conclusion is a basis for child's individual development program creation and providing a child with psychological and pedagogic assistance, including help from IRC specialists.

It should be mentioned that during 2018 new educational technologies of inclusive-resource centres work improvement were spread. All of this was defined in "The Organisational and Training Principles of Inclusive Resource Centres Activities" study guide. The guide contains recommendations for psychological-pedagogic coach teams for children with special educational needs at the institutions of general secondary and preschool education; it also gives advice to a psychological-pedagogic committee at a special general secondary education institution with regarding the successes or difficulties of a child mastering educational program, etc.

Another branch of special education development is school education quality survey monitoring. The National Academy of Pedagogical Sciences of Ukraine, along with the Ministry of Education of Ukraine, has developed the measures for creating a system of quality monitoring surveys of primary and secondary education. In addition to this, the plan for organizing national and participating in international monitoring surveys was confirmed for 2017-2029 years.

One of the most topical and the least investigated problems is a problem of early interference into the development of children with special educational needs (organization of early assessments of a child's development deviations and intervention at the age up to 3 years.) Early and preschool periods are namely sensitive periods of the most intensive psychological development. These periods include brain morpho-functional maturation, establishment of main conditional links that are fundamental for further personal and higher psychological functions development. In this respect, the practical use of interdisciplinary knowledge, creation state "early interference" system are the main goal for modern special education reform in Ukraine. Alternative "early interference" programs implementation demonstrated that systematic medical, psychological, and pedagogical help for the child enables upgrading a quality level of child's development process and significantly determines child's integration progress as an equal society member.

Developing organizational conditions to involve parents into individual correctivepedagogical work is an important condition to succeed while corrective-developmental working with little children who have development special features. There are several approaches to correct family situation of these children development. The crucial role of prophylactic work with troubled child's parents is indicated as measures to prevent a range of secondary child developmental deviations. The approaches and organization forms of professionals' work with a family are developed in order to shape parents' positive attitude to a child and to supply parents' mastering effective and accessible interaction forms to be used with a child in daily, emotional, and playing situations. Therefore, early psychological-pedagogic coach service creation in frames of special education reforming would strengthen system of corrective, developmental, pedagogical educational and therapeutic strategies and impacts, synthesizing development process elements.

\section{CONCLUSIONS}

Generally, it is crucially important to create in state on the level of educational needs a range of alternative psychological and pedagogical support models of free edu- 
cational forms' choice mechanisms for children with special needs. This approach is based on the following principles:

- stopping the practice of "tearing a child apart" from a family and society and supporting the child's natural socialization;

- development and implementation of alternative educational models for people with special needs and giving parents of children with special needs opportunities to choose future education forms and types.

Meanwhile, the following issues remain topical:

- further upgrade of legislation and regulations background regarding education of the aforementioned category of children;

- usage of special education institutions resources while providing interventional and developmental assistance for children with special needs being in inclusive conditions and professional advisory assistance for their parents and teachers;

- starting subject-oriented teaching for students with special needs both within an educational institution and specific classes (groups);

- further psychological and pedagogical education, development, and socialization principles development for children with various special features of psychophysical development, in particular for children with early autistic spectrum (EAS), overactive disorder and lack of attention (ODAL), and non-typical disorders;

- development of national and adjustment of international licensed psychological and pedagogical tools for the assessment of a child's development distortion;

- establishing strong links among all levels of education for children with special needs, including preschool institutions, schools, professional-technical, and higher educational institutions.

Intensification of activities in the aforementioned directions will allow, on the one hand, approaching educational requirements to common standards and, on the other hand, to provide an opportunity for children with special needs to obtain a desired level of educational and professional preparation, having herewith alternative of form of education and educational institution type.

\section{REFERENCES}

Kabinet Ministriv Ukrainy. (2017, July 12). Polozhennia pro inkliuzyvno-resursnyi tsentr [Regulations on Inclusive Resource Center]. Retrieved from http://zakon.rada.gov.ua/laws/ show/545-2017-\%D0\%BF

Ministerstvo osvity i nauky Ukrainy. (2016, December 14). Kontseptsiia "Novoi ukrainskoi shkoly" [Concept of "New Ukrainian School”]. Retrieved from https://mon.gov.ua/ua/tag/novaukrainska-shkola

Prokhorenko, L. (2018). Dytyna iz trudnoshchamy u navchanni. (Inkliuzyvne navchannia za nozolohiiamy) [A child with learning difficulties. (Inclusive study of nosology)]. Kharkiv: Ranok, VH "Kenhuru". (in Ukrainian)

Verkhovna Rada Ukrainy. (2017, September 5). Zakon Ukrainy "Pro osvitu” [Law of Ukraine "On Education"]. Retrieved from http://zakon.rada.gov.ua/laws/show/2145-19

Zasenko, V.V. (2015). Osoblyvi dity: osvita ta suprovid [Special children: education and support]. Svitohliad, 4, 12-15. 